Tasharruf: Journal Economics and Business of Islam Vol. 4, No. 2 (2019): 73-91

Website: http://journal.iain-manado.ac.id/index.php/TJEBI

ISSN 2528-0325 (online) ISSN 2528-0317 (print)

\title{
INTERNALISASI GOAL CONGRUANCE UNTUK PENDETEKSIAN FINANCIAL STATEMENT FRAUD \\ BERBASIS BEHAVIOUR AUDIT (Studi Kasus KAP Benny dan Rekan)
}

\author{
Jamaluddin Majid \\ Fakultas Ekonomi dan Bisnis Islam, Universitas Islam Negeri Alauddin Makassar, \\ Sulawesi Selatan, Indonesia. Jl, H. M. Yasin Limpo, No 21 Samata \\ Email: Jamalmajid75@gmail.com
}

\author{
Alfian Fani \\ Fakultas Ekonomi dan Bisnis Islam, Universitas Islam Negeri Alauddin Makassar, \\ Sulawesi Selatan, Indonesia. Jl, H. M. Yasin Limpo, No 21 Samata \\ Email:alfianfani69@gmail.com \\ Marwah Gama \\ Fakultas Ekonomi dan Bisnis Islam, Universitas Islam Negeri Alauddin Makassar, \\ Sulawesi Selatan, Indonesia. Jl, H. M. Yasin Limpo, No 21 Samata \\ Email: marwahgama455@gmail.com
}

\begin{abstract}
This research aims to reveal goal congruence for the financial statement fraud-based behavioral audit. financial statement fraud. The agency relationship theory is a contract between the auditor (agent) and the principal (principal). Agency relationships arise when one or more principals employ another person (agent) to provide a service and then delegate authority to decision making to the agent. This study was conducted at KAP Benny and colleagues using qualitative research using phenomenology approach using secondary data and primary data analyzed using interview and interview method using tools in the form of recorder and manuscript aid and tested its validity. The result of this research is shown by case from from 2015 to 2017. In 2015 there was $86.3 \%$ of cases, in 2016 there was $86.7 \%$ and down in 2017 by $3.68 \%$. Auditors' perception of goal congruence can help in achieving the goal of information that is not synchronized with other information. For that in building a good goal congruence then we need to build the ethics of an auditor.
\end{abstract}

Keywords: Behavior Auditor, Fraudulent Statement Fraud, Goal Congruence. 


\section{PENDAHULUAN}

Penerbitan laporan keuangan secara umum bertujuan untuk memberikan informasi mengenai posisi keuangan, kinerja dan arus kas perusahaan. Pelaporan keuangan bermanfaat bagi sebagian besar kalangan pengguna laporan dalam rangka membuat keputusan-keputusan ekonomi serta menunjukkan pertanggungjawaban manajemen atas penggunaan sumber-sumber daya yang dipercayakan kepada mereka (Ikatan Akuntan Indonesia, 2012). Oleh karena itu pelaku bisnis harus dapat memberikan informasi yang akurat dan relevan serta terbebas dari adanya kecurangan (fraud) yang akan sangat menyesatkan para pengguna laporan keuangan dalam proses pengambilan keputusan.

Association of Certified Fraud Examiners-ACFE dalam Report to the Nations on Occupational Fraud and Abuse (ACFE, 2018) menemukan sekitar $77 \%$ kecurangan dilakukan oleh individu melalui departemen seperti akuntansi, operasi, penjualan, eksekutif atau manajemen tingkat atas, layanan konsumen, pembelian dan keuangan. Selain itu, terjadi peningkatan pada sebagian besar jenis fraud salah satunya pada kecurangan laporan keuangan sebesar 9,0\%, meningkat dari tahun 2012 yang hanya 7,6 $\%$ (ACFE, 2018). Angka ini tidak terlalu besar jika dibandingkan dengan penyalahgunaan aset yang mencapai $85,4 \%$, tetapi kecurangan laporan keuangan menyebabkan dampak keuangan terbesar. Hal ini akan mengakibatkan informasi yang disajikan dalam laporan keuangan tidak relevan dan tidak dapat diandalkan.

Informasi tersebut dapat mempengaruhi pengambilan keputusan pihak eksternal dan internal perusahaan, serta dapat berpotensi munculnya pihak yang merasa dirugikan. Kecurangan (fraud) merupakan suatu tindakan yang dilakukan secara disengaja dan itu dilakukan untuk tujuan pribadi atau orang lain, dimana tindakan tersebut adalah telah menyebabkan kerugian bagi pihak tertentu atau institusi tertentu. Prasetyo (2011) menyatakan bahwa fraud adalah penyakit yang susah untuk disembuhkan. Maka dari itu untuk menangani penyakit, lebih baik mencegah daripada mengobatinya. Para ahli memperkirakan bahwa fraud yang terungkap merupakan bagian kecil dari seluruh fraud yang sebenarnya terjadi. Karena itu, upaya utama seharusnya adalah pada pencegahannya. Kecurangan ini merupakan suatu tindakan yang sudah berada diluar koridor prinsip akuntansi yang berlaku umum. Kecurangan mencakup tindakan illegal yang sengaja dilakukan, lalu disembunyikan dan memperoleh manfaat dengan melakukan pengubahan bentuk menjadi uang kas atau barang berharga lainnya. Tindakan ini dilakukan baik secara internal maupun eksternal, secara sengaja, dan disembunyikan (Annisya et al., 2016).

Majid dan Kartini (2016) mengungkapkan ada dua karakteristik terpenting yang harus ada dalam laporan keuangan yakni relevan dan dapat diandalkan. Tetapi kedua karakteristik ini sangatlah sulit untuk diukur, sehingga para pemakai informasi membutuhkan jasa pihak ketiga yaitu auditor yang independen. Auditor mempunyai peranan penting dalam menjembatani antara kepentingan pihak luar perusahaan seperti investor dan kepentingan perusahaan sebagai pemakai dan penyedia laporan keuangan. Rasuli (2009) auditor sebagai suatu profesi sangat berkepentingan dengan kualitas jasa 


\section{Tasharruf: Journal Economics and Business of Islam Vol. 4, No. 2 (2019): 73-91 Website: http://journal.iain-manado.ac.id/index.php/TJEBI ISSN 2528-0325 (online) ISSN 2528-0317 (print)}

audit (sebagai produk organisasi) agar jasa yang diberikan tersebut dapat diterima dan dipercaya oleh masyarakat. Dalam salah satu standar umum audit dinyatakan bahwa dalam pelaksanaan audit dan penyusunan laporan auditor wajib menggunakan kemahiran profesional dengan cermat dan seksama. Bahkan, standar pekerjaan lapangan juga mendukung hal ini dengan menyatakan bahwa bukti audit kompeten yang cukup harus diperoleh melalui inspeksi, pengamatan, permintaan keterangan, dan konfirmasi sebagai dasar yang memadai untuk menyatakan pendapat atas laporan keuangan yang diaudit. Seorang auditor yang skeptis, tidak akan menerima begitu saja penjelasan dari klien, tetapi akan mengajukan pertanyaan untuk memperoleh alasan, bukti dan konfirmasi mengenai obyek yang dipermasalahkan. Tanpa Goal congruance, auditor hanya akan menemukan salah saji yang disebabkan oleh kekeliruan saja dan sulit untuk menemukan salah saji dalam laporan keuangan yang disebabkan oleh kecurangan, karena kecurangan biasanya akan disembunyikan oleh pelakunya. Kegagalan auditor dalam mendeteksi kecurangan terbukti dengan adanya beberapa skandal keuangan yang melibatkan akuntan publik seperti Enron, Xerox, Walt Disney, World Com, Merck, dan Tyco yang terjadi di Amerika Serikat; selain itu juga kasus Kimia Farma dan sejumlah Bank Beku Operasi yang melibatkan akuntan publik di Indonesia, serta sejumlah kasus kegagalan keuangan lainnya.

Penelitian Beasley et al. (2001) yang didasarkan pada AAERs (Accounting and Auditing Releases) dari SEC selama 11 periode (Januari 1987 - Desember 1997) menyatakan bahwa salah satu penyebab kegagalan auditor dalam mendeteksi kecurangan adalah tidak adanya kesesuaian tujuan profesional audit atau goal congruence audit. Goal congruence merupakan keselarasan antara tindakan-tindakan individu untuk meraih tujuan-tujuan pribadi guna membantu pencapaian tujuan organisasi. Istilah goal congruence (keselarasan tujuan) diterapkan pada sebuah organisasi untuk memastikan bahwa semua operasi dan kegiatan ditetapkan dalam mendukung tujuan organisasi. Ini berarti bahwa organisasi akan meninjau semua operasi dan kegiatan untuk memastikan bahwa tidak satupun dari mereka (orang-operasi dan kegiatan) bekerja dengan cara yang membatasi atau menghambat kemampuan organisasi untuk mencapai tujuannya, apa pun bentuknya (Zagoel et al., 2008).

Aini (2001) setiap akuntan harus menjaga integritas dan keobjektivan dalam tugas profesional dan setiap auditor harus independen dari semua kepentingan yang bertentangan atau pengaruh yang tidak layak. Ia juga harus menghindari situasi yang dapat menimbulkan kesan pada pihak ketiga bahwa ada pertentangan kepentingan atau keobjektivan sudah tidak dapat dipertahankan Dari definisi di atas dapat ditarik kesimpulan bahwa sikap independensi auditor adalah sikap tidak memihak dan tidak mudah dipengaruhi oleh siapapun dan keadaan apapun, yang mana hal ini justru sangat diperlukan untuk mempertahankan kebebasan pendapatnya. Auditor tidak hanya berkewajiban mempertahankan sikap mental independensinya, tetapi ia harus pula menghindari keadaan-keadaan yang dapat mengakibatkan klien meragukan independensinya. Profesionalisme merupakan sikap dan prilaku auditor menggunakan pengetahuan, keterampilannya serta berpengalaman dalam pelaksanaan tugasnya sebagai auditor, sehingga memungkinkan auditor untuk memperoleh keyakinan yang memadai bahwa laporan keuangan klien bebas dari salah saji material, baik yang 
disebabkan oleh kekeliruan maupun kecurangan. Skeptisme profesional auditor adalah suatu sikap (attitude) dalam melakukan penugasan audit. Maka hal pertama yang akan dibahas adalah mengenai sikap manusia (Prasetyo, 2013). Dengan demikian kita bisa merumuskan rumusan di dalamnya yaitu trend dan potensi kecurangan laporan keuangan yang erat hubungannya dengan goal congruence serta bagaimana relas antara goal congruence dan behavioir audit yang bertujuan untuk membuat lembaga KAP bisa meningkatkan pelatihan untuk auditornya.

\section{TINJAUAN TEORITIS}

\section{a. Agency Theory}

Jensen dan Meckling (1976) menyatakan bahwa hubungan keagenan adalah sebuah kontrak antara auditor (agent) dengan klien (principal). Hubungan agensi muncul ketika satu orang atau lebih (principal) memperkerjakan orang lain (agent) untuk memberikan suatu jasa dan kemudian mendelegasikan wewenang pengambilan keputusan kepada agent tersebut. Dalam sebuah perusahaan, auditor berperan sebagai agent yang secara moral bertanggungjawab untuk mengoptimalkan keuntungan para klien (principal), namun disisi yang lain auditor juga mempunyai kepentingan memaksimumkan kesejahteraan mereka (Ujiyantho \& Pramuka, 2007). Conflict of interest atau perbedaan kepentingan antara prinsipal dan agen inilah yang dapat memicu agency problem yang dapat mempengaruhi kualitas laba yang dilaporkan. Menurut Eisenhardt (1989), teori agensi menggunakan tiga asumsi sifat manusia yaitu: (1) manusia pada umumnya mementingkan diri sendiri (selfinterest), (2) manusia memiliki daya pikir terbatas mengenai persepsi masa mendatang (bounded rationality), dan (3) manusia selalu menghindari risiko (riskaverse). Ketiga sifat tersebut menyebabkan informasi yang dihasilkan manusia untuk manusia lain selalu dipertanyakan reabilitasnya dan informasi yang disampaikan biasanya diterima tidak sesuai dengan kondisi perusahaan yang sebenarnya atau lebih dikenal sebagai informasi yang tidak simetris atau asymmetric information (Ujiyantho \& Pramuka, 2007).

\section{b. Goal Congruance}

Goal congruence merupakan keselarasan antara tindakan-tindakan individu untuk meraih tujuan-tujuan pribadi guna membantu pencapaian tujuan organisasi. Istilah goal congruence (keselarasan tujuan) diterapkan pada sebuah organisasi untuk memastikan bahwa semua operasi dan kegiatan ditetapkan dalam mendukung tujuan organisasi. Ini berarti bahwa organisasi akan meninjau semua operasi dan kegiatan untuk memastikan bahwa tidak satupun dari mereka (orang-operasi dan kegiatan) bekerja dengan cara yang membatasi atau menghambat kemampuan organisasi untuk mencapai tujuannya, apa pun bentuknya (Zagoel et al., 2008).

\section{c. Behaviour Audit}

Sebagai tambahan mengusulkan model interaksional pengambilan keputusan dalam organisasi. Perilaku tidak etis yang dilakukan individu dalam organisasi dapat diakibatkan oleh faktor-faktor perbedaan individual, situasional maupun interaksi 
antara faktor-faktor tersebut. Telaah empiris pengambilan keputusan etis yang menyatakan salah satu determinan penting pengambilan keputusan etis adalah faktorfaktor yang secara unik berhubungan dengan individu pembuat keputusan. Karena perilaku audit termasuk perilaku yang tidak etis, maka kecenderungan auditor melakukan tindakan audit dapat dipengaruhi karakteristik individual auditor (Sudirjo, 2013).

\section{d. Independensi}

Independensi merupakan salah satu komponen etika yang harus dijaga oleh akuntan publik. Independen berarti akuntan publik tidak mudah dipengaruhi, karena melaksanakan pekerjaan untuk kepentingan umum. Akuntan publik tidak dibenarkan memihak kepentingan siapapun. Auditor berkewajiban untuk jujur tidak hanya kepada manajemen dan pemilik perusahaan, namun juga kepada kreditur dan pihak lain yang meletakkan kepercayaan atas pekerjaan akuntan publik.

\section{e. Profesionalisme}

Profesionalisme yang meliputi kemampuan penguasaan baik secara teknis, maupun secara teoritis bidang keilmuan dan ketrampilan yang berhubungan dengan tugasnya, sebagai pemeriksa (Asri et al., 2014). Adanya keahlian dan kemampuan dalam melaksanakan pemeriksaan akan dapat mengetahui kekeliruan serta penyimpangan yang merupakan salah satu bagian kompetensi seorang auditor (Febrianty, 2012). Deva (2010) menyatakan profesionalisme menjadi syarat utama bagi seseorang yang menjadi auditor internal, sebab dengan profesionalisme yang tinggi, kebebasan auditor akan semakin terjamin. Usaha-usaha yang dilakukan untuk mendukung profesionalisme auditor yaitu dengan disusun dan disahkannya Kode Etik Ikatan Akuntan Indonesia oleh Ikatan Akuntan Indonesia (IAI).

\section{f. Skeptisme}

Skeptisisme, berasal dari kata skeptis, dalam Kamus Besar Bahasa Indonesia (Pusat Bahasa, 2008) dan kamus Oxford (Hornby, 1980) berarti sikap meragukan, mencurigai, dan tidak memercayai kebenaran suatu hal, teori, ataupun pernyataan. Dalam buku istilah akuntansi dan auditing, skeptisisme berarti bersikap ragu-ragu terhadap pernyataan-pernyataan yang belum cukup kuat dasar-dasar pembuktiannya (Islahuzzaman, 2012).

\section{g. Financial Statement Fraud}

Laporan keuangan adalah suatu laporan yang menggambarkan hasil dari proses akuntansi yang digunakan sebagai alat komunikasi untuk pihak-pihak yang berkepentingan dengan data keuangan atau aktivitas perusahaan. Putri (2013) laporan keuangan pada dasarnya adalah hasil dari prosesakuntansi yang dapat digunakan sebagai alat untuk mengkomunikasikan data keuangan atau aktivitas suatu perusahaan. 


\section{h. Goal Congruence untuk Mendeteksi Financial Statement Fraud}

Goal congruence merupakan keselarasan antara tindakan-tindakan individu untuk meraih tujuan-tujuan pribadi guna membantu pencapaian tujuan organisasi. Istilah goal congruence (keselarasan tujuan) diterapkan pada sebuah organisasi untuk memastikan bahwa semua operasi dan kegiatan ditetapkan dalam mendukung tujuan organisasi. Ini berarti bahwa organisasi akan meninjau semua operasi dan kegiatan untuk memastikan bahwa tidak satupun dari mereka (orang-operasi dan kegiatan) bekerja dengan cara yang membatasi atau menghambat kemampuan organisasi untuk mencapai tujuannya, apa pun bentuknya (Zagoel et al., 2008). Untuk mendeteksi kecurangan pada laporan keuangan harus memastikan faktor eksternal yaitu Faktor eksternal, yaitu norma-norma mengenai perilaku yang diharapkan terjadi dalam masyarakat (dan organisasi merupakan bagian dari masyarakat). Faktor -faktor eksternal yang mempengaruhi goal congruence adalah etos kerja dan norma spesifik sesuai industri. Etos kerja merupakan loyalitas seseorang terhadap organisasi, serta keuletan, semangat dan kebanggaan yang dimiliki dalam menjalankan tugas.

\section{i. Behaviour Audit untuk Mendeteksi Financial Statement Fraud}

Independensi merupakan salah satu komponen etika yang harus dijaga oleh akuntan publik. Independen berarti akuntan publik tidak mudah dipengaruhi, karena melaksanakan pekerjaan untuk kepentingan umum. Akuntan publik tidak dibenarkan memihak kepentingan siapapun. Auditor berkewajiban untuk jujur tidak hanya kepada manajemen dan pemilik perusahaan, namun juga kepada kreditur dan pihak lain yang meletakkan kepercayaan atas pekerjaan akuntan public. Dalam mendeteksi financial statement fraud menggunakan karakteristik independensi yaitu melalui penanaman karakter kejujuran. Independen itu lahir karena adanya suatu karakter kejujuran yang tertanam di dalam hatinya sehingga peran auditor dalam hal mendeteksi yaitu dengan cara melihat seorang akuntan gerak-gerik melalui karakter jujur itu. Untuk teknik dalam mendeteksi kecurangan laporan keuangan yaitu dengan teknik sembunyi-sembunyi artinya seorang auditor melihat kesehariannya dan melihat apakah dia independen atau malah mudah dipengaruhi oleh orang lain dalam hal pengambilan keputusan. Profesionlaisme dalam mendeteksi kecurangan pada laporan keuangan itu dengan melihat hasil data keuangan dan penugasannya secara teknis dan inilah yang menjadi perhatian khusus bagi seorang auditor dalam mendeteksi kecurangan. laporan keuangan skeptisme dijadikan sebagai metode inquiry sehingga seorang pembuat laporan keuangan mudah terperangkap dalam jebakan auditor menggunakan skeptisme seorang auditor.

\section{j. Peneliti Terdahulu}

Novianti (2008) mengenai "Skeptisme Profesionalisime auditor dalam mendeteksi kecurangan" bertujuan untuk memberikan masukan dalam menyusun standar dan aturan yang terkait dengan tindakan auditor dalam melakukan penugasan audit terutama yang berhubungan dengan pendeteksian kecurangan. Bagi pimpinan kantor akuntan publik dan auditor, dengan memahami faktor-faktor apa saja yang dapat mempengaruhi skeptisme profesional auditor, diharapkan pimpinan 


\section{Tasharruf: Journal Economics and Business of Islam Vol. 4, No. 2 (2019): 73-91 Website: http://journal.iain-manado.ac.id/index.php/TJEBI ISSN 2528-0325 (online) ISSN 2528-0317 (print)}

kantor dapat memotivasi auditor agar meningkatkan skeptisme profesionalnya dalam melakukan penugasan audit sehingga dapat meningkatkan kualitas audit. Penelitianmenggunakan Studi ini merupakan studi eksplanasi yang berkaitan dengan pengujian hipotesis dan dilakukan untuk mendapatkan pemahaman mengenai sifat hubungan tertentu, atau menentukan perbedaan antar kelompok atau kebebasan (independensi)dari dua atau lebih faktor. Padangan lain yang diutarakan. Penelitian ini berusaha untuk menjelaskan teori disonansi kognitif dari Festinger yang terjadi dalam setting auditing yang dapat mempengaruhi sikap skeptisme profesional auditor. Untuk itu dilakukan pengujian empiris dengan melihat pengaruh penaksiran risiko kecurangan pada auditor yang memiliki berbagai tingkat kepercayaan terhadap klien terhadap sikap skeptisme profesional auditor. Selain itu juga diuji apakah tipe kepribadian auditor akan mempengaruhi sikaskeptismenya.

Annisa dan Harris (2011) mengenai “ Deteksi indikasi fraud dengan teknologi audit" bertujuan untuk menemukan indikasi adanya tindakan fraud dalam penyajian laporan keuangan auditee. Sesuai Standar Audit seksi 327, dalam lingkungan sistem informasi akuntansi terkomputerisasi, maka tidaklah praktis. Penelitian ini lebih memfokuskan penelitian tentang penerapan Teknik Audit Berbantuan Komputer (TABK) dalam mendeteksi kemungkinan terjadinya fraud pada purchasing area, di mana peluang yang memicu terjadinya fraud di area tersebut salah satunya disebabkan oleh lemahnya pengendalian internal perusahaan. Penelitian ini merupakan penelitian kualitatif deskriptif. Alasan penulis menggunakan metode kualitatif adalah untuk mendapatkan data / informasi yang lebih lengkap, mendalam, kredibel dan bermakna, sehingga tujuan penelitian dapat dicapai. Penelitian ini menggunakan jenis data sekunder, artikel, buku maupun jurnal serta literature lain yang mendukung. Sumber data dalam penelitian ini berasal dari literatur seperti buku, jurnal penelitian, makalah, serta beberapa artikel terkait. Keterbatasan dalam penelitian ini adalah prosedur audit manual juga masih diperlukan. Hasil pengujian dari TABK hanya bersifat sebagai jembatan bagi auditor untuk menemukan gejala fraud dan melakukan investigasi lebih lanjut atas temuan yang di dapat. Sehingga pendekatan audit dalam lingkungan yang terkomputerisasi hendaknya mempertimbangkan suatu kombinasi antara teknik audit secara manual dan teknik audit berbantuan computer.

Annisya et al., (2016) dengan jurnalnya "Pendeteksian kecurangan laporan keuangan dengan menggunakan fraud diamond" bertujuan untuk menganalisis faktorfaktor yang mendorong laporan keuangan penipuan dengan analisis Frauds Diamond. Penelitian ini menganalisis pengaruh tekanan variabel proksi oleh stabilitas keuangan, tekanan eksternal, target keuangan, kesempatan ditunjukkan oleh sifat industri, razionalization proksi oleh opini audit, dan kemampuan untuk mengganti direksi proxy terhadap laporan keuangan penipuan. Sampel adalah total 27 perusahaan real estate dan real estate yang listing di Bursa Efek Indonesia pada periode 2010-2014. Hasil penelitian menunjukkan bahwa variabel stabilitas keuangan yang diukur dengan rasio perubahan total aset menunjukkan pengaruh positif terhadap laporan keuangan penipuan. Penelitian ini tidak menemukan tekanan eksternal variabel yang diukur dengan rasio leverage, target keuangan yang diukur dengan return on asset, sifat industri yang diukur dengan rasio perubahan 
persediaan, opini audit yang diukur dengan mendapatkan opini wajar tanpa pengecualian dengan bahasa mengklarifikasi, dan capablity diukur dengan perubahan direksi pengaruh pada laporan keuangan penipuan. Keterbatasan dalam penelitian ini adalah tidak menemukan variabel proksi lain yang dapat digunakan untuk mengetahui variabel lain yang diduga berpengaruh terhadap risiko terjadinya fraudulent financial statement.

\section{k. Penelitian Terdahulu}

Goal congruence merupakan keselarasan antara tindakan-tindakan individu untuk meraih tujuan-tujuan pribadi guna membantu pencapaian tujuan organisasi. Istilah goal congruence (keselarasan tujuan) diterapkan pada sebuah organisasi untuk memastikan bahwa semua operasi dan kegiatan ditetapkan dalam mendukung tujuan organisasi. Ini berarti bahwa organisasi akan meninjau semua operasi dan kegiatan untuk memastikan bahwa tidak satupun dari mereka.

\section{METODE PENELITIAN}

\section{Jenis Penelitia dan Pendekatan Penelitian}

Jenis penelitian yang digunakan dalam penelitian ini adalah kualitatif. Penelitian ini pada prinsipnya mendeskripsikan, menerangkan secara kritis, atau menggambarkan suatu fenomena, kejadian, atau peristiwa interaksi social dalam masyarakat untuk mencari dan menemukan makna dalam konteks sesungguhnya (Gumilang, 2016). Penelitian kualitatif merupakan penelitian yang digunakan untuk menyelidiki, menemukan, menggambarkan, dan menjelaskan kualitas atau keistimewaan dari pengaruh sosial yang tidak dapat dijelaskan, diukur atau digambarkan melalui pendekatan kuantitaif (Saryono, 2010: 1). Adapun pendekatan yang digunakan dalam penelitian ini adalah pendekatan fenomenologi. Pendekatan Fenomenologi adalah penelitian yang dilakukan dengan cara mengumpulakn dan merekap data dengan penjelasan didalamnya.

\section{Lokasi Penelitian}

Peneltian ini lebih berfokus kepada audit investigative yang ada di KAP Benny dan rekan yang berada di salah satu kota Makassar. KAP Benny dan rekan dipilih sebagai lokasi penelitian disebabkan KAP ini mempunyai auditor yang berpengalaman dalam mengaudit. Penelitian ini berlangsung 7 hari tepatnya 27 Juli- 2 Agustus. Proses interview dan presentasi mengenai goal congruence berbasis behavior audit kepada auditor investigative berlangsung 2 hari dan selanjutnya data diolah.

\section{HASIL DAN PEMBAHASAN}

\section{Gambaran Umum Perusahaan}

Obyek yang digunakan dalam penelitian ini adalah Kantor Akuntan Publik (KAP) yang ada di Makassar yaitu KAP Benny dan rekan. KAP ini sendiri di memiliki tanggungjawab mengaudit laporan keuangan historis yang di publikasikan oleh semua perusahaan yang terbuka, kebanyakan perusahaan yang lain cukup besar. Dengan 
demikian banyak perusahaan yang nonkomersial yang lebih kecil. Oleh karena luasnya penggunaan laporan keuangan yang telah diaudit dalam peroknomian di Indonesia. , serta keakraban dengan para pelaku bisnis dan pemakai lainnya, sudah lazim digunakan istilah auditor dan akuntan public.

\section{Struktur organisasi dalam KAP Benny dan rekan sebagai berikut.}

Kantor Konsultan Pajak Benny Gunawan \& Rekan di pimpin oleh Bapak Benny Gunawan sendiri dan dibantu oleh istrinya yang selaku komisaris kantor serta para karyawannya. Bapak Benny Gunawan memberikan kepercayaan kepada karyawannya untuk menangani urusan perpajakan kliennya. Berikut rincian tugas dari pimpinan, manajer operasional, supervisior, staff di KKP Benny Gunawan \& Rekan:

1. Pimpinan: Sebagai pimpinan, Bapak Benny Gunawan MM. Akt. CA. CPA mempunyai tugas untuk memimpin KKP dan bertanggung jawab terhadap kewajiban perpajakan klienya. Serta mengawasi pekerjaan karyawannya.

2. Manajer Operasional Sebagai Manajer Operasional, Bapak Isa Ansori ST mempunyai tugas untuk menangani dan bertanggung jawab atas seluruh operasional KKP.

3. SupervisiorSebagai Supervisor, Domo SE, Bella SE BKP Akt, Ardi SE, Dian SE mempunyai tugas mengecek ulang perhitungan pajak terutang yang telah dinuat oleh para staff sehingga pada saat pelaporan pembayaran tidak ditemukan nominal, nama, ataupun NPWP yang salah. Selain itu juga memegang peran dalam mengawasi para staff ketika pemilik sedang tidak ada di tempat.

4. Staf

Kantor Konsultan Pajak Benny Gunawan \& Rekan memiliki 9 staff (Agus SE, Gracia SE, Devina SE, Sarlin Amd, Singgih SE, Septi Amd, Hafidz Amd, Devina SE, Amelia SE) yaitu setiap masing- masing staff mempunyai tugas membantu supervisor untuk melakukan pengumpulan data yang digunakan dalam proses perhitungan perpajakan. Kantor Konsultan Pajak Benny Gunawan dan Rekan ini didirikan oleh Bapak Benny Gunawan sejak tahun 2010 kantor ini berada di Jalan Puri Anjasmoro Blok EE 1 No 6-7 Tawangsari Semarang. BG Tax Consulting merupakan badan usaha persekutuan (partnership) yang bergerak dibidang jasa perpajakan. Kantor Konsultan Pajak Benny Gunawan \& Rekan ini mempunyai perwakilan di Jakarta, Surabaya dan Yogyakarta. Sebagai konsultan pajak, KKP ini membantu banyak perusahaan di Indonesia untuk mengelola dan meminimalisir masalah perpajakan, serta mendorong kemajuan bisnis. Selain itu, KKP ini juga memberikan jasa analisis dan perhitungan pajak sesuai ketentuan yang berlaku. Solusi dari hasil analisis tersebut dapat membantu dalam penghematan biaya pajak serta membantu pengambilan strategi jangka panjang bisnis. Sampai saat ini KKP Benny Gunawan \& Rekan sudah memiliki kurang lebih 250 klien.

Visi Misi KAP Benny dan rekan sebagai berikut: 
Visi: Membangun Jasa Profesional dibidang Akuntansi dan Perpajakan yang handal dan terpercaya dengan mengutamakan Indepedensi, Kapabilitas, Integritas dan Moralitas sehingga memberikan manfaat sebesar-besarnya kepada StakeHolders.

Misi: Memberikan Jasa Profesional berdasarkan:

1. Best Quality Services/ Layanan Kualitas Terbaik.

2. Good Technical Skill/ Kemampuan Teknis yang Baik.

3. On Time Schedule/ Ketepatan waktu.

4. Work Smart/ Bekerja dengan Cerdas.

\section{PEMBAHASAN}

\section{Tren dan potensi pendeteksian financial statement fraud}

Fraudulent statement fraud melibatkan pemalsuan laporan keuangan dari perusahaan untuk penggunaan pribadi dengan menaikkan atau menurunkan nilai saldo. Penyalahgunaan aset ini disertai dengan catatan palsu atau dokumen untuk disembunyikan dan dijarah. Dengan demikian kita bisa mendefinisikan penyalahgunaan aset atau fraudulent statement fraud adalah suatu tindak pencurian. Penggelapan aset baik kas yang ada dibank ataupun kas yang ada ditangan atau disebut cash on hand (Majid et al., 2010). Adapun tren fraudulent statement fraud yang berpotensi memiliki resiko tinggi dan rendah anatara lain:

Grafik 4.1 Resiko Fraudulent statement fraud tahun 2018

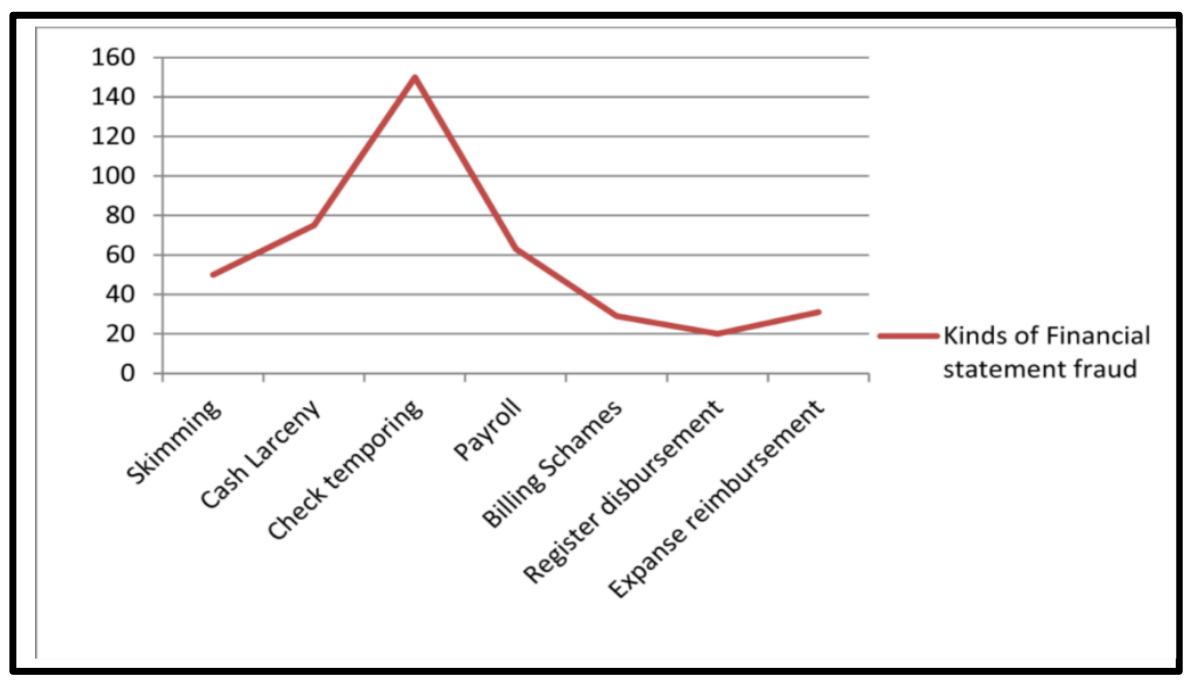

Sumber : Ilustrasi Peneliti ( ACFE Report of Nations , 2018)

Berdasarkan grafik 4.1 menyimpulkan bahwa laporan dari Association of certified fraud examiners (ACFE) terlihat bahwa fraudulent statement fraud paling besar tepatnya di skema pembayaran dan pemalsuan cek pada penjualan atau dalam istilah check tempering sebesar $\$ 150.000$ dengan kisaran $12 \%$ berpotensi beresiko besar terhadap kecurangan. Selanjutnya cash larceny merupakan suatu tindak pencurian uang mempunyai resiko terhadap penyelewengan aset berupa kas sebesar $\$ 75.000$ dengan kisaran $11 \%$. Payroll didefinisikan sebagai permainan atau penyelewengan terhadap gaji karyawan sekitar $\$ 63.000$ dengan kisaran $7 \%$. Pencurian 


\section{Tasharruf: Journal Economics and Business of Islam Vol. 4, No. 2 (2019): 73-91 Website: http://journal.iain-manado.ac.id/index.php/TJEBI ISSN 2528-0325 (online) ISSN 2528-0317 (print)}

kas sebelum masuk ke perusahaan atau lebih dikenal dengan istilah skimming sebesar $\$ 50.000$ dengan kisaran $11 \%$. Kecurangan terhadap biaya lalu dilakukanlah pembayaran dan dimanipulasi disebut expense reimbursement schemes sebesar \$31.000 dengan kisaran 14\%. Permainan terhadap pembebanan tagihan atau billing schemes dalam laporan ACFE sebesar \$29.000 dengan kisaran 3\% selanjunya yang terakhir adalah pengembalian uang yang dimanipulasi atau dalam istilah register disbursement sebesar $\$ 20.000$ dengan kisaran 15\% (ACFE, 2018)

Banyaknya kecurangan dalam lingkup suatu entitas termasuk kecurangan eksternal yang dilakukan oleh suatu invidual di luar lingkup perusahaan seperti kecurangan kartu kredit, investasi, pelanggan dan kecurangan yang diakibatkan oleh vendor ( Putri, 2014). Berdasarkan laporan ACFE (2018) diungkapkan terdapat tiga jenis kecurangan atau fraud terdiri atas korupsi, kecurangan laporan keuangan dan penyelewengan aset atau disebut fraudulent statement fraud. Berdasarkan tabel 1.1 dapat dilihat bahwa kecurangan penyelewengan aset adalah suatu fenomena yang terjadi dari tahun ke tahun. Hal ini ditunjukkan dengan kasus yang terjadi dari tahun 2015 sampai tahun 2017. Pada tahun 2015 terjadi 86,3\% kasus, tahun 2016 terdapat $86,7 \%$ dan turun pada tahun 2017 sebesar 3,68\%. Kategori fraudulent statement fraud ini sering terjadi namun hanya sedikit masyarakat yang mengetahuinya. Jika kita memperhatikan kehidupan sehari-hari, media hanya lebih mempertontonkan kasuskasus korupsi yang dilakukan oleh penyelenggara negara ataupun terkait kecurangan laporan keuangan oleh perusahaan-perusahaan yang besar dibandingkan dengan jenis kecurangan lainnya. Ada beberapa alasan mengapa fraudulent statement fraud sulit untuk dideteksi keberadaannya. Pertama, tidak adanya perhatian mengenai fraudulent statement fraud dalam suatu organisasi baik pencegahan maupun pendeteksian (Meikhati dan Rahayu, 2015). Kedua, banyaknya teknik yang kurang efektif dalam mendeteksi adanya kecurangan (Amara et al., 2013).

Kasus fraudulent statement fraud merupakan suatu kasus yang terbilang masih kurang yang mengetahui oleh karena itu hal ini sangat menarik perhatian seoarang auditor untuk mengambil sebuah langkah-langkah guna mendeteksi adanya fraudulent statement fraud yaitu dengan menggunakan behaviour audit. Prasetyo (2015) mengemukakan cara efektif untuk mendeteksi adanya kecurangan adalah dengan melihat tanda, sinyal atau behaviour audit yang yang terindikasi adanya kecurangan akan tetapi metode behaviour audit ini masih bersifat tradisional yang artinya masih melibatkan checklist fraud perilaku (Bierstaker et al., 2006). Keberadaan behaviour audit tidak meramalkan adanya fraudulent statement fraud tetapi merupakan kondisi yang berhubungan dengan fraudulent statement fraud. Whistleblowing juga merupakan metode yang paling efektif dalam mendeteksi adanya fraudulent statement fraud yang dimana cara kerjanya yakni melaporkan pelanggaran yang terjadi pada suatu organisasi terutama tindak fraudulent statement fraud. Whistleblowing ini merupakan suatu sistem yang berbasis web dengan tujuan amanah dan menyalurkan, mengadukan suatu masalah terhadap penyimpangan yang ada di dalam maupun di luar perusahaan Data mining juga merupakan salah cara untuk mendeteksi adanya kecurangan terkhusus untuk fraudulent statement fraud yang ada di daerah pertambangan atau lingkup perusahaan pertambangan dengan menggunakan teknik 
analisis rasio, k-mens dan memperhatikan asset tracking atau pelacakan aset serta pemrograman genetic. (Meenatkshi dan Sivaranjani, 2016).

Grafik 4.2 Efektivitas metode pencegahan dan pendeteksian kecurangan

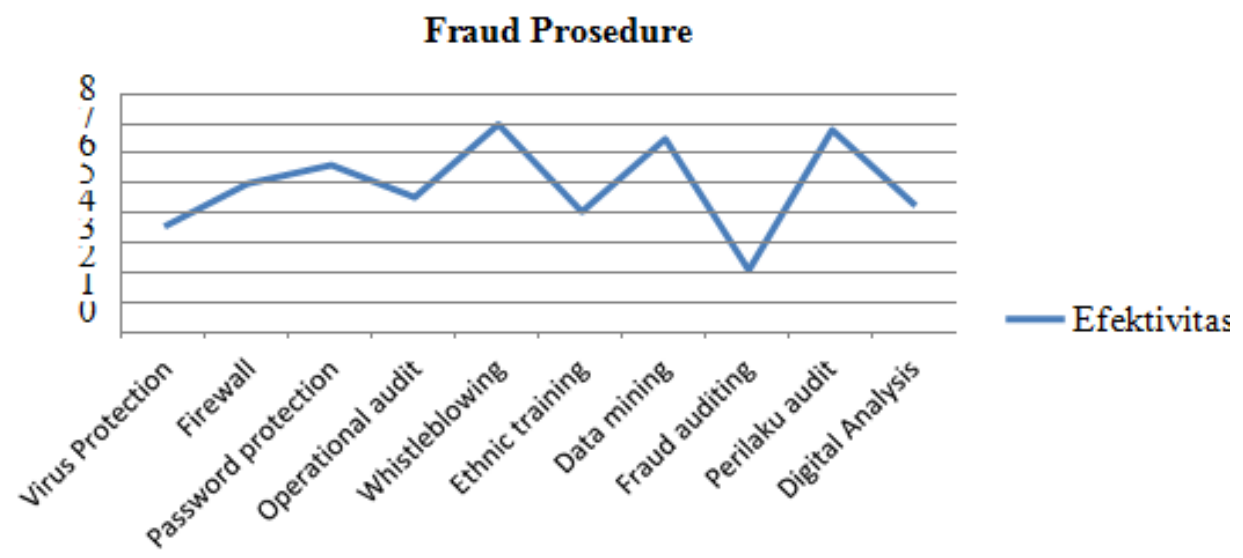

Sumber: Ilustrasi Penulis ( Bierstaker et al., 2006)

Dari data grafik 4.2 diatas terlihat bahwa proteksi virus, firewall, operasional audit, pelatihan etika dan analisis digital tidak efektif dalam pendeteksian dan pencegahan terhadap fraudulent statement fraud ditinjau dari beberapa presepsi yakni baik secara keuangan maupun segi penggunaan metode. Goal congruance adalah suatu model untuk mendeteksi dan mencegah adanya kecurangan melalui pernacangan model dalam bentuk prosedur audit dalam bentuk flagel, data mining dan whistleblowing. Ketiga metode ini agan bertransformasi menjadi sesuatu kekuatan seorang audit invesatigatif dalam mendeteksi suatu fraudulent statement fraud. Seklain itu juga perlindungan password juga menjadi pengendalian internal dengan tujuan untuk keamanan data melalui computer dengan menggunakan pola berdasarkan instruksi sehinggan menjadi suatu pencengahan fraudulent statement yang aman (Richariya dan Singh, 2012).

\section{Presepsi auditor mengenai relasi goal congruance untuk behaviour auditor}

Berdasarkan hasil wawancara yang dilakukan di KAP Benny daan rekan ini menghasilkan beberapa penelitian dalam penelitian ini adalah Goal congruence merupakan keselarasan yang dilakukan pada auditor eksternal yang berprofesi di KAP yang berisi tentang tindakan-tindakan individu atau sekelompok dalam rangka untuk membantu pencapaian tujuan dalam suatu KAP. Menurut hasil wawancara yang dilakukan di KAP benny dan rekan goal congruence dijadikan sebagai suatu karakteristik yang yang dimiliki oleh seorang auditor dalam rangka membenatu pencapaian suksesnya seorang auditor. Dengan demikian, goal congruence ini sangat berperan penting untuk menjadi ethinc training yang memiliki kegaiata dalam kegiatan opersional hal ini dibuktikan dengan pengopersasian goal congruence dalam membentuk suatu etika seorang auditor sehingga diantara mereka tidak akan terjadi hambatan terhadap kecurangan. Dengan adanya goal congruence bisa membantu 


\section{Tasharruf: Journal Economics and Business of Islam Vol. 4, No. 2 (2019): 73-91 Website: http://journal.iain-manado.ac.id/index.php/TJEBI ISSN 2528-0325 (online) ISSN 2528-0317 (print)}

dalam hal pencapaian tujuan antara informasi yang tidak sinkronisasi dengan informasi yang lainnya. Untuk itu dalam membangun suatu goal congruence yang baik maka kita perlu membina etika seorang auditor. Sebagaimana yang dilakukan oleh KAP Benny dan rekan membibit suatu auditor dengan pelatihan etika hal ini berkaitan dengan pendeteksian kecurangan dalam suatu entitas yang diaudit. KAP Benny dan rekan ini mulai memberikan traing etika dengan tujuan untuk merealisiasikan dan menghasilkan temuan yang relevan dan simetris.

Partner KAP dan rekan pada saat diwawancarai di tempat mengatakan bahwa pelatihan etika yang sering diberikan itu adalah sebulan sekali hal ini dikarenakan banyaknya suatu kasus kecurangan terutama pada laporan penyajian laporan keuangan pada suatu entitas. Dengan demikian pelatihan etika ini memiliki beberapa fungsi yaitu membibit seorang auditor yang independensi, profesionalisme dan skeptisme terhadap pendeteksian kecurangan laporang keuangan. Independensi merupakan salah satu komponen etika yang harus dijaga oleh akuntan publik. Independen berarti akuntan publik tidak mudah dipengaruhi, karena melaksanakanp pekerjaan untuk kepentingan umum. Akuntan publik tidak dibenarkan memihak kepentingan siapapun. Profesionalisme yang meliputi kemampuan penguasaan baik secara teknis, maupun secara teoritis bidang keilmuan dan ketrampilan yang berhubungan dengan tugasnya, sebagai pemeriksa dan yang terakhir adalah terkait skeptisme seorang auditor yaitu sikap meragukan, mencurigai, dan tidak memercayai kebenaran suatu hal, teori, ataupun pernyataan. Dalam buku istilah akuntansi dan auditing, skeptisisme berarti bersikap ragu-ragu terhadap pernyataan- pernyataan yang belum cukup kuat dasar-dasar pembuktiannya. Ketika sikap auditor ini akan mampu mendeteksi kecurangan tertuama pada penyajian laporan keuangan sehingga mengasilkan kesuaian tujuan atau disebut dengan goal congruence. Pendeteksian terhadap kecurangan laporan keuangan yang baik tergantung dari etika dan perilaku seorang auditor untuk menciptakan keselarasan tujuan antara clien dan seorang auditor.

\section{Goal congruence untuk mendeteksi financial statement fraud berbasis behavior audit}

Penerbitan laporan keuangan secara umum bertujuan untuk memberikan informasi mengenai posisi keuangan, kinerja dan arus kas perusahaan.Pelaporan keuangan bermanfaat bagi sebagian besar kalangan pengguna laporan dalam rangka membuat keputusan-keputusan ekonomi serta menunjukkan pertanggungjawaban manajemen atas penggunaan sumbersumber daya yang dipercayakan kepada mereka (Ikatan Akuntan Indonesia, 2007). Oleh karena itu pelaku bisnis harus dapat memberikan informasi yang akurat dan relevan serta terbebas dari adanya kecurangan (fraud) yang akan sangat menyesatkan para pengguna laporan keuangan dalam proses pengambilan keputusan. Association of Certified Fraud Examiners-ACFE dalam Report to the Nations on Occupational Fraud and Abuse (ACFE, 2018) menemukan sekitar $77 \%$ kecurangan dilakukan oleh individu melalui departemen seperti akuntansi, operasi, penjualan, eksekutif atau manajemen tingkat atas, layanan konsumen, pebelian dan keuangan. Selain itu, terjadi peningkatan pada sebagian besar jenis fraud salah satunya pada kecurangan laporan keuangan sebesar 9,0 \%, meningkat dari tahun 2012 yang hanya 7,6 \% (ACFE, 2018). Angka ini tidak terlalu besar jika dibandingkan dengan penyalahgunaan aset yang mencapai $85,4 \%$, tetapi kecurangan laporan 


\section{Tasharruf: Journal Economics and Business of Islam Vol. 4, No. 2 (2019): 73-91 Website: http://journal.iain-manado.ac.id/index.php/TJEBI ISSN 2528-0325 (online) ISSN 2528-0317 (print)}

keuangan menyebabkan dampak keuangan terbesar Fraudulent statement fraud melibatkan pemalsuan laporan keuangan dari perusahaan untuk penggunaan pribadi dengan menaikkan atau menurunkan nilai saldo. Penyalahgunaan aset ini disertai dengan catatan palsu atau dokumen untuk disembunyikan dan dijarah. Dengan demikian kita bisa mendefinisikan penyalahgunaan aset atau fraudulent statement fraud adalah suatu tindak pencurian. Penggelapan aset baik kas yang ada dibank ataupun kas yang ada ditangan atau disebut cash on hand (Majid et al., 2010).

Prasetyo (2011) menyatakan bahwa fraud adalah penyakit yang susah untuk disembuhkan. Maka dari itu untuk menangani penyakit, lebih baik mencegah daripada mengobatinya. Para ahli memperkirakan bahwa fraud yang terungkap merupakan bagian kecil dari seluruh fraud yang sebenarnya terjadi. Karena itu, upaya utama seharusnya adalah pada pencegahannya. Kecurangan ini merupakan suatu tindakan yang sudah berada diluar koridor prinsip akuntansi yang berlaku umum. Kategori financial statement fraud ini sering terjadi namun hanya sedikit masyarakat yang mengatahinya. Jika kita memperhatikan kehidupan sehari-hari, media hanya lebih mempertontonkan kasus-kasus korupsi yang dilakukan oleh penyelenggara negara ataupun terkait kecurangan laporan keuangan oleh perusahaan- perusahaan yang besar dibandingkan dengan jenis kecurangan lainnya. Ada beberapa alasan mengapa financial statement fraud sulit untuk dideteksi keberadaanya. Pertama, tidak adanya perhatian mengenai financial statement fraud dalam suatu organisasi baik pencegahan maupun pendeteksian ( Meikhati dan Rahayu, 2015). Kedua, banyaknya teknik yang kurang efektif dalam mendeteksi adanya kecurangan (Amara et al., 2013). Kasus financial statement fraud merupakan suatu kasus yang terbilang masih kurang yang mengatahui oleh karena itu hal ini sangat menarik perhatian seoarang auditor untuk mengambil sebuah langkah-langkah guna mendeteksi adanya financial statement fraud yaitu dengan menggunakan Goal congruence.

Goal congruence merupakan keselarasan antara tindakan-tindakan individu untuk meraih tujuan-tujuan pribadi guna membantu pencapaian tujuan organisasi. Istilah goal congruence (keselarasan tujuan) diterapkan pada sebuah organisasi untuk memastikan bahwa semua operasi dan kegiatan ditetapkan dalam mendukung tujuan organisasi. Ini berarti bahwa organisasi akan meninjau semua operasi dan kegiatan untuk memastikan bahwa tidak satupun dari mereka (orang-operasi dan kegiatan) bekerja dengan cara yang membatasi atau menghambat kemampuan organisasi untuk mencapai tujuannya, apa pun bentuknya (Zagoel et al., 2008).

Untuk mendeteksi kecurangan pada laporan keuangan harus memastikan faktor eksternal yaitu faktor eksternal, yaitu norma-norma mengenai perilaku yang diharapkan terjadi dalam masyarakat (dan organisasi merupakan bagian dari masyarakat). Trevino (1986) mengusulkan model interaksional pengambilan keputusan dalam organisasi. Menurut Trevino (1986) perilaku tidak etis yang dilakukan individu dalam organisasi dapat diakibatkan oleh faktor-faktor perbedaan individual,situasional maupun interaksi antara faktor-faktor tersebut. Pendapat tersebut didukung oleh Forddan Richardson (1994) dalam telaah empiris pengambilan keputusan etis yang menyatakansalah satu determinan penting pengambilankeputusan etis adalah faktor-faktor yang secara unik berhubungan dengan individu pembuat keputusan. Karena perilaku audit termasuk 
perilaku yang tidak etis, maka kecenderungan auditor melakukan tindakan audit dapat dipengaruhi karakteristik individual auditor (Sudirjo, 2013). Dengan demikian adanya perilaku yang tidak etis mak diperlukan suatu karakter seorang auditor untuk pengambilan keputusan sehingga bisa untuk mendeteksi kecurangan laporan keuangan atau financial statement fraud.

Dalam mendeteksi financial statement fraud menggunakan karakteristik independensi yaitu melalui penanaman karakter kejujuran. Independen itu lahir karena adanya suatu karakter kejujuran yang tertanam didal hatinya sehingga peran auditor dalam hal mendeteksi yaitu dengan cara melihat seorang akuntan gerak-gerik melalui karakter jujur itu. Untuk teknik dalam mendeteksi kecurangan laporan keungan yaitu dengan teknik sembunyi-sembunyi artinya seorang auditor melihay kesehariannya dan melihat apakah dia independen atau malah mudah dipengaruhi oleh orang lain dalam hal pengambilan keputusan. Profesionlaisme dalam mendeteksi kecurangan pada laporan keuangan itun dengan melihat hasil data keuangan dan penugasannya secara teknis dan inilah yang menjadi perhatian khusus bagi seorang auditor dalam mendeteksi kecurangan. Pendeteksian fraud laporan keuangan skeptisme dijadikan sebagai metode inquiry sehingga seorang pembuat laporan keuangan mudah terperangkap dalam jebakan auditor menggunakan skeptisme seorang auditor.

\section{PENUTUP}

Pada bab empat telah dilakukan analisis atas hasil penelitian. Pada bab ini disajikan rangkuman dalam hasil penelitian. Pembahasan ini meliputi kesimpulan, saran dan keterbatasan untuk penelitian mendatang.

\section{Kesimpulan}

Setelah menelaan dan kemudian melakukan analisis pembahasan maka peneliti menyimpulkan :

1. Fraudulent statement fraud melibatkan pemalsuan laporan keuangan dari perusahaan untuk penggunaan pribadi dengan menaikkan atau menurunkan nilai saldo . Penyalahgunaan aset ini disertai dengan catatan palsu atau dokumen untuk disembunyikan dan dijarah. Dengan demikian kita bisa mendefinisikan penyalahgunaan aset atau fraudulent statement fraud adalah suatu tindak pencurian. Dapat dilihat bahwa kecurangan penyelewengan aset adalah suatu fenomena yang terjadi dari tahun ke tahun. Hal ini ditunjukkan dengan kasus yang terjadi dari tahun 2015 sampai tahun 2017. Pada tahun 2015 terjadi 86,3\% kasus, tahun 2016 terdapat $86,7 \%$ dan turun pada tahun 2017 sebesar 3,68\%.

2. Persepsi auditor mengenai goal congruence bisa membantu dalam hal pencapaian tujuan antara informasi yang tidak sinkronisasi dengan informasi yang lainnya. Untuk itu dalam membangun suatu goal congruence yang baik maka kita perlu membina etika seorang auditor. Dengan demikian, etika ini sangat penting karena bisa mengubah perilaku seorang auditor melalui pelatihan etika auditor. 
3. Kasus financial statement fraud merupakan suatu kasus yang terbilang masih kurang yang mengatahui oleh karena itu hal ini sangat menarik perhatian seoarang auditor untuk mengambil sebuah langkah-langkah guna mendeteksi adanya financial statement fraud yaitu dengan menggunakan Goal congruence. Adanya perilaku yang tidak etis mak diperlukan suatu karakter seorang auditor untuk pengambilan keputusan sehingga bisa untuk mendeteksi kecurangan laporan keuangan atau financial statement fraud.

\section{Saran}

Adapun saran yang diusulkan dalam penelitian ini adalah sebagai berikut;

1. Untuk Investor, kreditur dan pemegang saham Sebaiknya berhati-hati dan lebih skeptic dalam memperhatikan informasi keuangan, terkait masalah kecurangan pelaporan keuangan. Para praktisi diharapkan mampu menganalisa laporan keuangan perusahaan agar dapat mengetahui kondisi perusahaan yang sebenarnya.

2. Untuk auditor, sebaiknya lebih meningkatkan pelatihan perilaku dalam rangka peninhkatan goal congruence dalam mendeteksi kecurangan laporan keuangan.

3. Untuk peneliti selanjutnya, lebih kepada kedalaman materi terkait dengan goal congruence untuk proses pendekteksian fraud.

\section{DAFTAR PUSTAKA}

Aini, L. P. 2001. Teori kecurangan farud awwanes dan metodologi untuk mendeteksi kecurangan pelaporan keuangan. Jurnal ekonomi dan audit, 4(2): 1-15.

Amara, rahmawati, dan kemal. 2013. Mendeteksi kecurangan laporan keuangan. Jurnal akuntansi. 1(2): 124-139.

Annisa, R., dan haris 2011. Good governance practice for better performance of community organization-myths and realities. Joural of power, politics dan governance, 1(1): 10-27.

Annisyah, a., L. Sari, dan asmaranti. 2016. Pendeteksian kecurangan menggunakan pendekatan fraud diamond, jurnal ekonomi dan bisnis, 1(2): 34-45.

Anugerah, hermansyah, ahmad. N. 2011. Pengaruh independensi auditor terhadap kualitas audit. Jurnal akuntansi. 4(1): 105-125.

Ardini. 2010. Model Deteksi Kecurangan Berbasis Fraud Triangel (Studi Kasus Pada Perusahaan Publik di Indonesia). Jurnal Akuntansi dan Auditing, 9(2): 199-225. 
Arens, L., Pany, K., and ketty, J. 2011. Quality control, premature sign offs and underreporting of time. Auditing: A Journal of Practice and Theory, 5(2), 50 63.

Asri, R. A. Alfarizi dan N. Rahmat. 2014. Analisis Determinan Financial Statement Melalui Pendekatan Fraud Triangel. Accounting Analysis Journal. 4(1): $1-14$.

Badjuri, L. S. 2010. Auditor size and Auditor quality. Journal of Accounting and Economics, 3, $183-199$.

Basu. 2009. Kecurangan akuntansi (fraud accounting) dalam perspektif islam. Jyrnal akuntansi dan bisnis, 2(1): 93-109.

Beasley, R.M, Kenny, D.A. and Andre, E. 2001. The moderator-mediator variable: Conceptual, strategic and statistical consideration. Journal of Personality and Social Psychology. Vol 26 (10): 1-15.

Biastaker, T.,Malone, C. F., \& Roberts, R. W. 2016. Factors associated with the incidence of reduced audit quality behaviours. Auditing: A Journal of Practice and Theory, 15(2), $49-64$.

Brennan, C. W., and mcgrat, J. W. 2007. Auditors' perception of time budget pressures and premature sign offs: A replication and extension. Auditing: A Journal of Practice and Theory, 1(2), 54- 68.

Deva, H. J. 2010. The Operation of Control Systems in Large Audit Firms. Auditing: A Journal of Practice and Theory, 15(2), 65 - 84.

Eisen, H. 1989. Locus of control, Machiavellianism, and Managerial Job Performance.The Journal of Psychology. Vol 128, 599 - 608.

Febrianty, L. 2014. Pengaruh Fraud Indicator Terhadap Fraudulent Financial Statement: Studi Empiris pada Perusahaan yang Listed di Bursa Efek Indonesia (BEI)Tahun 2008-2013. Diponegoro Journal of Accounting, 4(4): 1-15.

Forddan. 1994. Development of the work locus of control scale. Journal of Occupational Psychology. 11(1): 118 - 125.

Gemilang, M. 2016. Implementasi Pemerintahan yang Bersih dalam Kerangka Rencana Aksi Daerah Pemberantasan Korupsi (RAD-PK). Jurnal Dinamika Hukum, 12(3): 448-463.

Hurtt, L. N. (2003). Under-reporting and premature sign-off in public accounting firm. Managerial Accounting Journal. Vol 18 (4): , 478 - 489.

Islahuzzaman. 2012. Financial Statement Fraud: Incidents, Methods and Motives. Australian Accounting Review, 17 (2): 49-61. 


\section{Tasharruf: Journal Economics and Business of Islam Vol. 4, No. 2 (2019): 73-91 Website: http://journal.iain-manado.ac.id/index.php/TJEBI ISSN 2528-0325 (online) ISSN 2528-0317 (print)}

Jensen, P., and macklin, J. J. 1976. Auditor acceptance of dysfunctional audit behaviour: An explanatory model using personal characteristics. Behavioural Research In Accounting, 15, 87 -110.

Lesmana dan muchdar. 2015. Analisis Faktor - Faktor yang Mempengaruhi Kecurangan laporan Keuangan (Studi Empiris pada Perusahaan Non Keuangan yang Terdaftar di Bursa Efek Indonesia Tahun 2008 - 2011). Diponegoro Journal of Accounting, 3 (1): 1-11.

Lowers, K.M. 2011. Turnover among DP Personnel: A causal Analysis. Communications of the ACM. 26,807-811.

Majid, J. Dan Kartini. 2016. Potret Hubungan Auditor-Klien: Sebuah Studi Interaksi Simbolik Kantor Akuntan Public. Jurnal ilmiah akuntansi perdaban, 2(1): 148162.

Mekhati dan rahayu. 2017. Analisis faktor faktor yang mempengaruhi kecurangan pelaporan keuangan publik indonesia. Jurnal ekonomi dan bisnis. 3(1): 25-40.

Novianty, N. 2008. Quality control, premature sign offs and underreporting of time. Auditing: A Journal of Practice and Theory, 5(2), 50 - 63

Prasetyo. 2011. Pengaruh manajemen laba terhadap biaya modal ekuitas (studi pada perusahaan publik). Simposium nasional akuntansi (SNA) Denpasar, 963-974.

Prasetyo. 2013. Model pendeteksian kecurangan dengan menggunakan fraud tringel. Jurnal akuntansi dan auditing, 1(2): 199-225.

Putry, A., M. Muhlis dan J. Kumala. 2013. Suatu perspektif tentang klaim mal praktekauditing forensik dan audit kecurangan. Jurnal stie semarang. 2(1): 1-15.

Quadackers, P.E. (2009). Development of the work locus of control scale. Journal of Occupational Psychology. 11 (1): $118-125$.

Rasuli. 2009. Corporate governance. Jurnal ekonomi dan bisnis. 2(1): 67-80.

Rezaee, J.M. 2002. Machiavellianism and Inner vs. Outer directedness: A study of sales managers. Psychological Reports. Vol 56, 81 - 82.

Richardson, C. 2017. The Impact of Time Budget Pressure, Personality and Leadership Variables on Dysfunctional Audit Behavior. Auditing: A Journal of Practice and Theory, 9(2): $21-42$.

Richaria, dan sing. 2012. Under-reporting and premature sign-off in public accounting firm. Managerial Accounting Journal.18(6): 478 - 489.

Sudirjo, A. 2013. Analisis Fraud Diamond dalam Mendeteksi Financial Statement Fraud: Studi Empiris pada Perusahaan Manufaktur yang Terdaftar di Bursa Efek 
Tasharruf: Journal Economics and Business of Islam Vol. 4, No. 2 (2019): 73-91 Website: http://journal.iain-manado.ac.id/index.php/TJEBI ISSN 2528-0325 (online) ISSN 2528-0317 (print)

Indonesia (BEI) Tahun 2010-2012. Diponegoro Journal of Accounting, 3(2): 2135 .

Susiana, P.and arlin. 2007. Detecting Earning Management: A New Approach. Journal of Accounting Research, 50(2): 275-334.

Trevino, D. C. C. 1986. Progression from ideal state to good governance: an introductory overview. International journal of business and management studies, 9(1): 29-49.

Zagoel, S. M., Adams, S. J., \& Lightner, K. M. 2008. The influence of situational, ethical and expectancy theory variables on accountants' underreporting behaviour. Auditing: A Journal of Practice and Theory, 5(1), 1 - 12. 